\title{
KONTRIBUSI ASUPAN ENERGI PROTEIN DAN MAKANAN JAJANAN PADA SISWA OBESITAS DI SEKOLAH MENENGAH PERTAMA NEGERI 4 MANADO
}

\author{
Fred A. Rumagit ${ }^{1}$, Phembriah S. Kereh², Juan Rori ${ }^{3}$ \\ Jurusan Gizi Poltekkes Kemenkes Manado \\ fredarumagit@gmail.com
}

\begin{abstract}
The problem of obesity and obesity in Indonesia occurs in all age groups and in all socioeconomic strata. Data Riskesdas in 2007 showed that the prevalence of obesity in Indonesia in adolescents aged 15 years and over by 19.1\%, while for ages 6-14 years obesity prevalence for male gender of $9.5 \%$ and women $8.0 \%$ (Balitbangkes, 2007). The purpose of this study is to find out how the contribution of energy intake, protein intake and food snacks in obese students in SMP Negeri 4 Manado. The method in this research is observational research using Cross Sectional study design, with bivariate analysis of fisher's exact test test. Sampling technique purposive sampling. The population in this study is students of SMP Negeri 4 Manado, the sample consists of 32 male and female students in SMP Negeri 4 Manado. Measurement of dependent variable of obesity and independent variable of energy and protein intake, food snack. The results showed that 31 (96.9\%) respondents had energy intake level> 90\%, and $6(18,7 \%)$ respondents had protein intake level> $90 \%$. Most of the energy and protein intake obtained comes from food snacks. In conclusion There is a relationship between energy and protein intake derived from home-based food and snacks with obesity nutritional status.

Keywords: Energy intake, Protein intake, Food Snack and Obesity.
\end{abstract}

\section{Pendahuluan}

Upaya perbaikan gizi masyarakat sebagaimana disebutkan dalam UndangUndang Nomor 36 Tahun 2009 tentang Kesehatan, bertujuan untuk meningkatkan mutu gizi perseorangan dan masyarakat, antara lain melalui perbaikan pola konsumsi makanan, perbaikan perilaku sadar gizi, peningkatan akses dan mutu pelayanan gizi serta kesehatan sesuai dengan kemajuan ilmu dan teknologi (Kemenkes, 2015).

Obesitas disebabkan multifaktor, di dalamnya terdapat komponen genetik dan perilaku. Kebiasaan makan dan aktivitas fisik merupakan bagian dari komponen perilaku, dimana keduanya dipengaruhi faktor lingkungan, sosial ekonomi, dan budaya. Obesitas merupakan akibat ketidakseimbangan antara asupan energi dan keluaran energi dalam jangka waktu lama sehingga terjadi penimbunan jaringan lemak berlebihan (Restuastuti, dkk 2014).

Masalah kegemukan dan obesitas di Indonesia terjadi pada semua kelompok umur dan pada semua strata sosial ekonomi. Pada anak sekolah, kejadian kegemukan dan obesitas merupakan masalah yang serius karena akan berlanjut hingga masa dewasa. Pada anak remaja, kegemukan dan obesitas juga dapat mengakibatkan berbagai masalah kesehatan yang sangat merugikan kualitas hidup anak seperti gangguan pertumbuhan tungkai kaki, gangguan tidur, sleep apnea (henti napas sesaat) dan gangguan pernafasan lain (Kemenkes, 2011).

Kekurangan dan kelebihan gizi muncul karena pola makan bergizi tak seimbang. Kekurangan gizi terjadi akibat asupan gizi dibawah kebutuhan, sedangkan kelebihan gizi timbul karena asupan gizi melebihi kebutuhan. Adapun kelebihan gizi terjadi, terutama, karena pola makan yang padat energi (kalori) dan melebihi kebutuhan untuk beraktivitas sehingga menimbulkan kegemukan akibat kelebihan energi (Nakita, 2010). Terlalu sering mengkonsumsi makanan jajanan akan mempengaruhi status gizi karena 
makanan jajanan tersebut kebanyakan mengandung tinggi/ karbohidrat sehingga membuat cepat kenyang, selain itu kebersihan dan stardar gizi dari makanan jajanan itu sendiri masih diragukan (Triasih A, 2010).

Data Riskesdas pada tahun 2007 menunjukan bahwa prevalensi obesitas di Indonesia pada remaja usia 15 tahun keatas sebesar 19,1\%, sedangkan untuk usia 614 tahun prevalensi obesitas untuk jenis kelamin laki-laki sebesar $9,5 \%$ dan perempuan 8,0\% (Balitbangkes, 2007).

Berdasarkan data Riskesdas tahun (2013) bahwa Prevalensi gemuk pada remaja umur 13-15 tahun di Indonesia sebesar 10,8\%, terdiri dari 8,3\% gemuk dan $2,5 \%$ sangat gemuk (obesitas). Sebanyak 13 provinsi dengan prevalensi gemuk diatas nasional, yaitu Jawa Timur, Kepulauan Riau, DKI, Sumatera Selatan, Kalimantan Barat, Bangka belitung, bali, Kalimantan Timur, Lampug, Sulawesi Utara, dan Papua. Prevalensi penduduk obesitas terendah di provinsi Nusa Tenggara Timur $(18,2 \%)$ dan tertinggi di Sulawesi Utara $(24,0 \%)$. Enam belas provinsi dengan prevalensi diatas nasional, yaitu Jawa Barat, Bali, Papua, Di Yogyakarta, Aceh, Sulawesi Tengah, Jawa Timur, Bangka Belitung, Sumetera Utara, Papua Barat, Kepuluan Riau, Maluku Utara, Kalimantan Timur, DKI Jakarta, Gorontalo, dan Sulawesi Utara (Balitbangkes, 2013).

Hasil riset kesehatan dasar Sulawesi Utara tahun 2013 dari 15 kabupaten / kota, di Kota Manado ke empat tertinggi prevalensi gemuk pada anak remaja dengan persentase 3,7\% (Dinkes, 2013). Besarkan hasil survey data yang di ambil di SMP Negeri 4 Manado bahwa jumlah murid dari kelas 7-8 berjumlah 628 orang, ketika dilakukan pengukuran berat badan dan tinggi badan didapatkan jumlah murid yang memiliki berat badan lebih (Obesitas) sebanyak 85 orang. Maka mendorong penulis untuk melakukan penelitian tentang Kontribusi Asupan Energi Protein Dan Makanan Jajanan Pada Siswa Obesitas Di Sekolah Menengah Pertama (SMP) Negeri 4 Manado

\section{METODE}

Jenis penelitian adalah penelitian observasional dengan menggunakan rancangan studi Cross Sectional, Penelitian ini dilaksanakan di SMP Negeri 4 Manado, yaitu pada bulan Oktober 2017. Populasi adalah semua siswa dan siswi kelas 7-8 di SMP Negeri 4 Manado yang overweight/obesitas yang berjumlah 85 orang. Besar sampel dalam penelitian ini ditentukan berdasakan rumus besar sampel untuk data proporsi populasi terbatas (Lemeshow, 1997), yaitu sebanyak 32 orang dengan kriteria sampel bersedia menjadi responden dalam penelitian dan tidak dalam keadaan sakit. Pengumpulan data dilakukan dengan cara wawancara dan memberikan kuesioner, instrument dalam penelitian ini yaitu kuesioner, timbangan BB dan microtoise dan food recall 24 jam. Dalam pengolahan dan analisis data diawali dengan proses editing dan coding data, untuk memudahkan prosese pemasukan data kemudian dilanjutkan dengan mengentri data pada mengecek kelengkapan data serta pembuatan tabel tabulasi. Analisis univariat untuk mengetahui karakteristik dan distribusi frekuensi variabel subjek penelitian dan disajikan dalam bentuk tabel dan pembahasan yang sesuai dengan realita yang ada. Analisis bivariat dilakukan menggunakan uji fhisher's exact test, untuk mengetahui hubungan asupan energi, protein makanan dan makanan jajanan dengan obesitas, dianalisa dengan menggunakan program Statistikal Product and Service Solution (SPSS). 


\begin{tabular}{|c|c|c|}
\hline \multirow[t]{2}{*}{ Umur Responden (tahun) } & \multicolumn{2}{|c|}{ Jumlah } \\
\hline & $\mathrm{n}$ & $\%$ \\
\hline 12-13 tahun & 25 & 78.1 \\
\hline 14 tahun & 7 & 21.8 \\
\hline Jumlah & 32 & 100 \\
\hline \multirow[t]{2}{*}{ Jenis Kelamin } & \multicolumn{2}{|c|}{ Jumlah } \\
\hline & $\mathrm{n}$ & $\%$ \\
\hline Laki-laki & 16 & 50.0 \\
\hline Perempuan & 16 & 50.0 \\
\hline Jumlah & 32 & 100 \\
\hline \multirow[t]{2}{*}{ Agama } & \multicolumn{2}{|c|}{ Jumlah } \\
\hline & $\mathrm{n}$ & $\%$ \\
\hline Islam & 6 & 18.8 \\
\hline Katolik & 2 & 6.2 \\
\hline Kristen Protestan & 24 & 75.0 \\
\hline Jumlah & 32 & 100 \\
\hline \multirow[t]{2}{*}{ Status Gizi } & \multicolumn{2}{|c|}{ Jumlah } \\
\hline & $\mathrm{n}$ & $\%$ \\
\hline Overweight & 17 & 53.1 \\
\hline Obesitas & 15 & 46.9 \\
\hline Jumlah & 32 & 100 \\
\hline
\end{tabular}

Berdasarkan tabel di atas menunjukkan bahwa distribusi responden yang berumur 12-13 tahun sebanyak 25 responden (78.1\%) dan umur 14 tahun sebanyak 7 responden (21.8\%). Selanjutnya distribusi responden menurut jenis kelamin, dari 32 responden diantaranya yang berjenis kelamin laki-laki 16 responden $(50.0 \%)$, dan yang berjenis kelamin perempuan 16 responden (50.0\%). Distribusi responden menurut agama, dari 32 responden yaitu agama Islam berjumlah 6 orang (18.8\%), Katolik berjumlah 2 orang $(6.2 \%)$ dan Kristen Protestan 24 orang (75.0\%). Sedangkan, berdasarkan hasil penelitian terhadap 32 siswa di SMP Negeri 4 Manado terdapat 53.1 $\%$ siswa status gizi gemuk dan $46.9 \%$ siswa status gizi obesitas.

Tabel 2. Distribusi Frekuensi Asupan Energi Makanan Rumahan

\begin{tabular}{|c|c|c|}
\hline \multirow[t]{2}{*}{ Asupan Energi } & \multicolumn{2}{|c|}{ Frekuensi } \\
\hline & $\mathrm{n}$ & $\%$ \\
\hline Baik (>90 \% kebutuhan) & 31 & 96.9 \\
\hline Kurang (<90 \% kebutuhan) & 1 & 3.1 \\
\hline Jumlah & 32 & 100 \\
\hline \multirow[t]{2}{*}{ Asupan Protein } & \multicolumn{2}{|c|}{ Frekuensi } \\
\hline & $\mathrm{n}$ & $\%$ \\
\hline Baik (>90\% kebutuhan) & 30 & 93.8 \\
\hline Kurang (<90\% kebutuhan) & 2 & 6.2 \\
\hline Jumlah & 32 & 100 \\
\hline Variabel & & \\
\hline
\end{tabular}




\begin{tabular}{|c|c|c|c|c|c|}
\hline & \multicolumn{2}{|c|}{ Obesitas } & \multicolumn{2}{|c|}{ Overweight } & \\
\hline Energi dari Rumahan & $\mathrm{n}$ & $\%$ & $\mathrm{n}$ & $\%$ & \\
\hline Baik (>90\% kebutuhan) & 1 & 3.1 & 6 & 18.7 & \\
\hline Kurang (<90\% kebutuhan) & 16 & 50.0 & 9 & 28.2 & \\
\hline Jumlah & 17 & 53.1 & 15 & 46.9 & \\
\hline \multirow{2}{*}{ Variabel } & \multicolumn{4}{|c|}{ Status Gizi } & \multirow{2}{*}{$p^{\text {value }}$} \\
\hline & \multicolumn{2}{|c|}{ Obesitas } & \multicolumn{2}{|c|}{ Overweight } & \\
\hline Energi (Jajanan) & $\mathrm{n}$ & $\%$ & $\mathrm{n}$ & $\%$ & \\
\hline Sering (>90 \% kebutuhan) & 7 & 21.8 & 12 & 37.5 & 0,029 \\
\hline Jarang (<90 \% kebutuhan) & 10 & 31.3 & 3 & 9.4 & \\
\hline Jumlah & 17 & 53.1 & 15 & 46.9 & \\
\hline
\end{tabular}

Berdasarkan hasil penelitian untuk distribusi frekwensi asupan energi rumahan terhadap 32 responden menunjukkan bahwa 31 (96.9\%) responden termasuk distribusi frekuensi asupan energi makanan rumahan dengan kategori baik dan $3.1 \%$ responden termasuk kategori kurang. Sedangkan distribusi asupan protein makanan rumahan dari 32 responden, dimana 30 responden (93.8\%) termasuk kategori baik dan 2 responden $(6.2 \%)$ termasuk kategori kurang.

Sementara itu, responden dengan asupan energi makanan rumahan kategori baik dengan obesitas 1 orang (3.1\%), dan responden dengan asupan energi kurang dengan obesitas 16 orang (50\%). Selanjutnya responden dengan asupan energi baik tapi overweight 6 orang $(18.7 \%)$ dan responden dengan asupan energi kurang tapi overweight 9 rang (28.2\%). Dari hasil di atas dilakukan uji statistik Fhisher's Exact diperoleh hasil terdapat hubungan antara asupan energi makanan dari rumah dengan status obesitas pada anak SMP dimana nilai $p=0.033$.

Responden dengan asupan energi makanan jajanan kategori sering dan obesitas 7 orang (21.8\%), dan responden dengan asupan energi makanan jajanan dengan kategori jarang tapi obesitas 10 orang (31.3\%). Selanjutnya untuk responden dengan asupan energi makanan jajanan dengan kategori sering dan overweight 12 orang (37.5\%) sedangkan responden dengan asupan energi makanan jajanan kategori jarang tapi overweight 3 orang (9.4\%). Berdasarkan hasil ini maka dilakukan uji statistik Fisher Exact dan diperoleh hasil terdapat hubungan antara asupan energi makanan jajanan dan status obesitas pada anak SMP Negeri 4 Manado dengan nilai $p=0,029$

Tabel 3. Hubungan Asupan dengan Obesitas Siswa SMP Negeri 4 Manado

\begin{tabular}{|c|c|c|c|c|c|}
\hline \multirow{2}{*}{ Variabel } & \multicolumn{4}{|c|}{ Status Gizi } & \multirow{2}{*}{$p^{\text {value }}$} \\
\hline & \multicolumn{2}{|c|}{ Obesitas } & \multicolumn{2}{|c|}{ Overweight } & \\
\hline Protein Makanan Rumahan & $n$ & $\%$ & $n$ & $\%$ & \multirow{3}{*}{0,006} \\
\hline Baik (>90 \% kebutuhan) & 0 & 0.0 & 6 & 18.7 & \\
\hline Kurang (<90 \% kebutuhan) & 17 & 53.1 & 9 & 28.2 & \\
\hline Jumlah & 17 & 53.1 & 15 & 46.9 & \\
\hline \multirow{2}{*}{ Variabel } & \multicolumn{4}{|c|}{ Status Gizi } & \multirow{2}{*}{$p^{\text {value }}$} \\
\hline & \multicolumn{2}{|c|}{ Obesitas } & \multicolumn{2}{|c|}{ Overweight } & \\
\hline Energi Jajanan & $\mathrm{n}$ & $\%$ & $\mathrm{n}$ & $\%$ & \multirow{3}{*}{0,032} \\
\hline Sering (>90 \% kebutuhan) & 5 & 15.6 & 11 & 34.4 & \\
\hline Jarang (<90 \% kebutuhan) & 12 & 37.5 & 4 & 12.5 & \\
\hline Jumlah & 17 & 53.1 & 15 & 46.9 & \\
\hline Rata - rata Sehari & \multicolumn{2}{|c|}{ Kebutuhan } & \multicolumn{3}{|c|}{ Tingkat Konsumsi } \\
\hline
\end{tabular}




\begin{tabular}{lccc}
\hline & & & $(\%)$ \\
\hline Energi (kkal) & 1923.5 & 2125 & 90.5 \\
Protein (g) & 55.7 & 69 & 80.7 \\
\hline & & & \\
\hline Rata - rata Sehari & Konsumsi & Kebutuhan & Tingkat Konsumsi \\
\cline { 2 - 4 } & & & $(\%)$ \\
\hline Energi (kkal) & 1870.53 & 2125 & 88.0 \\
Protein (g) & 55.8 & 69 & 80.9 \\
\hline
\end{tabular}

Tabel 3 menunjukkan bahwa responden dengan asupan protein makanan rumahan kategori baik tapi obesitas 0 dan responden dengan asupan protein kurang tapi obesitas 17 orang (53.1\%). Selanjutnya responden dengan asupan energi baik tapi overweight 6 orang (18.7\%) dan responden dengan asupan energi kurang tapi overweight 9 rang (28.2\%). Dari hasil di atas dilakukan uji statistik Fhisher's Exact diperoleh hasil terdapat hubungan antara asupan energi makanan dari rumah dengan status obesitas pada anak SMP dimana nilai $p=0.006$.

Responden dengan asupan protein makanan jajanan kategori baik tapi obesitas $5(15.6 \%)$ dan responden dengan asupan protein kurang tapi obesitas 12 orang (37.5\%). Selanjuitnya responden dengan asupan energi baik tapi overweight 11 orang $(34.4 \%)$ dan responden dengan asupan energi kurang tapi overweight 4 orang (12.5\%). Dari hasil di atas dilakukan uji statistik Fhisher's Exact diperoleh hasil terdapat hubungan antara asupan energi makanan dari rumah dengan status obesitas pada anak SMP dimana nilai $p=0.032$.

Hasil penelitian pun menunjukkan bahwa tentang rata-rata konsumsi energi dan protein makanan rumahan, dimana tingkat konsumsi energi $90.5 \%$ dan tingkat konsumsi protein $80.7 \%$. Adapun, rata-rata tingkat konsumsi energi makanan jajanan $88.0 \%$ dan protein $80.9 \%$. Padahal, jika dibandingkan dengan rata-rata tingkat konsumsi energi dan protein makanan rumahan ternyata tingkat konsumsi energi dan protein yang berasal dari jajanan masih lebih tinggi .

\section{PEMBAHASAN}

Berpedoman pada program PMT-AS, makanan jajanan diharapkan mempunyai mutu gizi kurang lebih 200-300 kkal untuk menyumbangkan kurang lebih 10-20\% terhadap total konsumsi energi. Pada penelitian ini diperoleh 32 anak usia sekolah mengkonsumsi makanan jajanan dalam jumlah yang lebih. Maka energi makanan jajanan yang dikonsumsi oleh anak usia sekolah tidak sesuai karena melebihi $10-20 \%$ kkal dari kebutuhan energi (Febry, 2006). Konsumsi makanan jajajanan anak usia sekolah di atas dalam jumlah yang lebih cukup mengkhawatirkan karena tumbuh dan berkembangnya anak usia sekolah yang optimal tergantung dari beberapa hal, diantaranya adalah pemberian nutrisi dengan kualitas sesuai dengan kebutuhan.

Asupan energi dari makanan jajan yang diperoleh sebagian besar berasal dari makanan yang cenderung mengandung tinggi energi dan karbohidrat sederhana sebagai sumber energi. Selain itu juga siswa gemar untuk mengkonsumsi makanan jajanan di kantin dan di luar rumah dibandingkan mengkonsumsi makanan dari rumah (Shintia, 2016).

Jenis zat gizi yang dikonsumsi oleh tubuh antara lain protein, karbohidrat dan lemak, masing-masing zat gizi berbeda. Makanan yang padat energi disertai dengan kurangnya aktivitas fisik dan akan disimpan sebagai lemak sehingga menyebabkan 
obesitas. Hal ini sejalan dengan penelitian (Weni Kurdanti, 2015) menyatakan bahwa peranan makanan cepat saji sangat berperan untuk memberikan kontribusi energi sebesar $10-25 \%$ terhadap asupan energi dan mengkonsumsi makanan sumber energi tinggi seperti nasi 3-4x sehari dan konsumsi dari bihun, mie, kentang dan ketela sangat tinggi. Sehingga ada beberapa faktor penting yang menyumbang kejadian obesitas pada anak remaja tanpa memperhatikan asupan zat gizi terutama asupan energi Sesuai hasil uji statistik yaitu fhisher's exact test dengan nilai signifikan yaitu $(0,032<\alpha(0.05)$, artinya $\mathrm{H}_{0}$ ditolak, sehingga dapat disimpulkan terdapat hubungan asupan energi dengan obesitas. Penelitian ini sejalan dengan (Terry A, 2010) yang menyatakan ada hubungan antara asupan energi dengan obesitas.

Berdasarkan hasil penelitian menyatakan bahwa asupan energi yang berlebih merupakan penyebab utama terjadinya masalah masalah kegemukan (obesitas). Kelebihan asupan energi atau karbohidrat akan disimpan dalam bentuk glikogen dan lemak. Glikogen akan disimpan di hati dan otot. Lemak akan disimpan disekitar perut, ginjal dan di bawah kulit. Oleh karena itu kelebihan energi dan karbohidrat dapat menyebabkan obesitas. Obesitas pada anak beresiko tinggi menjadi obesitas dimasa dewasa dan berpotensi mengalami penyakit degeneratif (WHO, 2000).

Hasil penelitian ini menunjukkan terdapat hubungan antara asupan energi protein dan makanan jajanan dengan status obesitas pada siswa SMP negeri 4 Manado. Hal ini menjelaskan bahwa siswa yang mendapatkan asupan energi dari makanan jajanan lebih 300 kkal beresiko mengalami obesitas. Kurangnya aktifitas fisik juga merupakan faktor penyebab terjadinya kegemukan dan obesitas pada kalangan anak sekolah. Kemajuan teknologi berupa alat elektronik seperti video games, playstation, komputer menyebabkan anak kurang beraktifitas yang menyebabkan jumlah kalori yang dibakar lebih sedikit jika dibandingkan kalori yang diperoleh dari makanan sehingga terjadi penimbunan lemak berlebih dalam tubuh (Kemenkes, 2009).

Selain itu kejadian obesitas pada anak sering dikaitkan dengan kejadian obesitas pada orang tuanya. Karena genetik memegang peranan penting dalam mempengaruhi berat dan komposisi tubuh seseorang. Jika kedua orang tua mengalami obesitas kemnungkinan besar anak-anak juga menderita obesitas $75-80 \%$. Jika salah satu orang tuanya mengalami obesitas kemungkinan tersebut hanya $40 \%$. Sedangkan jika tidak seorangpun dari orang tuanya mengalami obesitas, peluangnya kurang dari 10\% (Manurung, 2009)

Selanjutnya hasil penelitian menyatakan bahwa asupan protein secara langsung memiliki hubungan dengan obesitas. Dalam keadaan berlebihan protein akan mengalami pelepasan dari gugus amino. Oleh karena itu, bila seseorang mengkonsumsi banyak protein dalam makanan maka akan disimpan sebagai lemak dalam tubuh. Almatsier juga menjelaskan bahwa dalam keadaan berlebihan protein akan mengalami deaminase. Nitrogen dikeluarkan dari tubuh dan sisa-sisa ikatan karbon akan diubah menjadi lemak dan disimpan di dalam tubuh, dengan demikian konsumsi protein secara berlebihan juga dapat meyebabkan kegemukan dan obesitas. Sesuai hasil uji statistic yaitu fhisher's exact test dengan nilai signifikan yaitu $(0,015)<\alpha$ (0.05), artinya $\mathrm{H}_{0}$ ditolak, sehingga dapat disimpulkan terdapat hubungan asupan protein dengan obesitas. Penelitian ini sejalan dengan (I Gunnarsdottir, 2010) yang menyatakan ada hubungan antara asupan protein dengan obesitas.

Makanan jajanan (street food) sudah menjadi bagian yang tidak terpisahkan dari kehidupan masyarakat, baik di perkotaan maupun di pedesaan. Konsumsi makanan jajanan di masyarakat di perkirakan terus meningkat mengingat makin terbatasnya waktu anggota keluarga untuk mengolah makanan sendiri. Keunggulan makanan jajanan adalah murah dan mudah di dapat, serta cita rasanya yang enak dan cocok 
dengan selera kebanyakan masyarakat. Makanan jajanan seringkali lebih banyak mengandung unsur karbohidrat dan hanya sedikit mengandung protein, vitamin atau mineral. Karena ketidaklengkapan gizi dalam makanan jajanan, maka pada dasarnya makanan jajanan tidak dapat menggantikan sarapan pagi atau makan siang. Anakanak yang banyak mengkonsumsi makanan jajanan perutnya akan merasa kenyang karena padatnya kalori yang masuk ke dalam tubuhnya. Sementara gizi seperti protein, vitamin dan mineral masih sangat kurang (Agiatmi, 2005).

Di dalam tubuh, protein mempunyai peranan yang sangat penting. Fungsi utamanya sebagai zat pembangun atau pembentuk struktur sel, misalnya untuk pembentukan otot. Penelitian terhadap 80 anak SD di Denpasar tahun 2004, menunjukkan bahwa $75 \%$ konsumsi energi anak-anak tersebut berasal dari jajanan (junk food), hanya $25 \%$ konsumsi energi dari makanan pokok berupa nasi, lauk pauk, sayuran dan pelengkapnya rambut, kulit, membran sel, jantung, hati, ginjal, dan beberapa organ penting lainnya. Sesuai hasil uji statistic yaitu fhisher's exact test dengan nilai signifikan yaitu $(0,026)<\alpha(0.05)$, artinya $\mathrm{H}_{0}$ ditolak, sehingga dapat disimpulkan terdapat hubungan makanan jajanan pada asupan energi dengan obesitas, dan sesuai hasil uji statistic yaitu fhisher's exact test dengan nilai signifikan yaitu $(0,013)<\alpha(0.05)$, artinya $\mathrm{H}_{0}$ ditolak, sehingga dapat disimpulkan terdapat hubungan pada asupan protein dengan obesitas.

Kontribusi makanan jajanan sebaiknya tidak dihilangkan dari konsumsi harian, karena memberikan sumbangan yang cukup berarti. Makanan jajanan juga dapat dijadikan salah satu alternatif pemenuhan sumber zat gizi yang kurang dari konsumsi hariannya. Kajian makanan jajanan di afrika menyebutkan bahwa makanan jajanan memberikan kontribusi energi sepertiga dan seperempat vitamin dan mineral dari konsumsi harian. Makanan jajanan yang dibeli anak umumnya mengenyangkan dan kaya akan energi dan lemak, namun sangat kurang zat gizi mikro (Yunita S, 2009).

Makanan jajanan memegan peranan penting dalam memberikan kontribusi tambahan untuk kecukupan gizi khususnya energi dan protein. Kebiasaan jajan disekolah terjadi karena 3-4 jam setelah makan pagi perut akan terasa lapar kembali. Makanan jajanan sebaiknya tidak dikonsumsi pada waktu makan utama. Namun konsumsi makanan jajanan yang berlebihan juga dapat menyebabkan peningkatan berat badan apabila pilihan jajanan berupa makanan yang tinggi kalori, lemak, gula dan rendah zat gizi yang dibutuhkan oleh anak-anak (Bondika, 2011).

Menurut Almatsier juga menjelaskan bahwa dalam keadaan berlebihan, protein akan mengalami deaminase. Nitrogen dikeluarkan dari tubuh dan sisa-sisa ikatan karbon akan diubah menjadi lemak dan disimpan di dalam tubuh, dengan demikian konsumsi protein secara berlebihan juga dapat menyebabkan kegemukan dan obesitas.

\section{KESIMPULAN}

Kontribusi asupan energi yang bersumber dari makanan jajanan dengan jumlah rata-rata 1870.53 kalori (88\%) dan kontribusi asupan protein yang bersumber dari makanan jajanan rata-rata 55.8 gram (80.9\%) pada siswa obesitas di Sekolah Menengah Pertama (SMP) Negeri 1 Manado. Kontribusi asupan energi yang bersumber dari makanan rumahan rata-rata dengan jumlah rata-rata 1923.5 kalori (90.5\%) dan asupan protein 55.7 gram (80.7\%) pada siswa obesitas di Sekolah Menengah Pertama (SMP) Negeri 1 Manado. Sehingga terdapat hubungan kontribusi antara asupan energi dan protein yang berasal dari makanan rumahan maupun jajanan dengan status gizi obesitas.

Adapun saran bagi Sekolah konsumsi makanan baik di sekolah maupun di rumah untuk memenuhi kebutuhan energi dan zat gizi anak perlu ditingkatkan. Anak 
perlu dibiasakan untuk mengkonsusmsi makanan yang beraneka ragam, menyukai sayur dan buah agar tercukupi kebutuhan vitamin. Peran orang tua murid dalam mendidik dan memberikan pendidikan gizi diluar pendidikan formal sekolah perlu ditingkatkan agar anak dapat memilih dan membedakan antara makanan jajanan sehat dan tidak sehat. Demikian pula, orang tua hendaknya menyediakan jajanan sehat di rumah agar anak terhindar dari mengonsumsi jajanan tidak sehat yang banyak terdapat di luar rumah. untuk penelitian selanjutnya diharapkan penelitian ini dapat menjadi data awal untuk penelitian selanjutnya, yaitu upaya yang efektif dalam meningkatkan pemilihan jajanan yang baik pada usia sekolah.

\section{DAFTAR PUSTAKA}

Almatsier, 2009. Prinsip IImu Gizi Dasar. Gramedia Pustaka Utama. Jakarta Almatsier, Soetardjo, \& Soekatri, 2011. Gizi Seimbang Dalam Daur Kehidupan. PT Gramedia Pustaka Utama. Jakarta

Balitbangkes RI, (2007). Penyajian Pokok-Pokok Hasil Riset Kesehatan Dasar. Badan Penelitian dan Pengembangan Kesehatan Departemen Kesehatan, Republik Indonesia, Jakarta.

Balitbangkes RI, (2013). Penyajian Pokok-Pokok Hasil Riset Kesehatan Dasar. Badan Penelitian dan Pengembangan Kesehatan Departemen Kesehatan, Jakarta.

Depertemen Kesehatan RI, 2013. Penyajian Pokok-Pokok Hasil Riset Kesehatan Dasar.Badan Penelitian dan Pengembangan Kesehatan Departemen Kesehatan, Republik Indonesia. Badan Litbang Kesehatan. Jakarta.

Hasdianah, Siyoto \& Peristyowati 2014. Gizi Pemanfaatan Gizi dan Obesitas. Penerbit Nuha Medika. Jakarta.

Kemenkes RI, 2011. Modul Pelatihan Pelayanan Kesehatan Peduli Remaja. Kementerian Kesehatan RI, Jakarta.

Kemenkes RI, 2011. Pedoman Pencegahan dan Penganggulangan Kegemukan dan Obesitas pada Anak Sekolah. Kementerian Kesehatan RI, Jakarta.

Kemenkes RI, 2012. Strategi Nasional Penerapan Pola Konsumsi Makanan dan Aktivitas Fisik untuk Mencegah Penyakit Tidak Menular. Kementerian Kesehatan RI. Jakarta

Kemenkes RI, 2012. Pedoman Pencegahan dan Penanggulangan Kegemukan dan Obesititas pada Anak Sekolah http://ejournal.unsrat.ac.id/index.php/ebiomedik/artikele/viewFile/4371/390 $\underline{0}$ (Diakses 20 Desember 2017)

Kemenkes RI, 2013. Pedoman Keamanan Pangan Jajanan Anak Sekolah. Kementerian Kesehatan RI. Jakarta.

Kemenkes RI, 2014.Pedoman Surveilans Gizi. Kementerian Kesehatan RI, Jakarta

Kemenkes RI, 2015. Petunjuk pelaksanaan Surveilans Gizi. Kementerian Kesehatan RI, Jakarta.

Lemeshow, S, Hosmer,D, W, Klar, J. \& Lwanga, S. K, (1997). Besar Sampel Dalam Penelitian Kesehatan Yokyakarta, Gajah Mada University Press.

Manurung, Nelly K. 2009. Pengaruh Karakteristik Remaja, Genetika, Pendapatan Keluarga, Pendidikan Ibvu, Pola Makan, dan Aktifitas Fisik Terhadap Kejadian Obesitas Di SMU RK Tri Skti Medan (Tesis). USU Medan.

Nakita, 2010. Sehat Dan Bugar Berkat Gizi Seimbang.Yayasan Institut Danone.

Persagi, (2016).Konseling Gizi. Penerbit Penebar Plus. Jakarta. 
GIZIDO Volume 11 No.1 Mei 2019 Kontribusi Asupan Fred Rumagit dkk

Supariasa, (2012). Pendidikan dan Konsultasi Gizi. Penerbit Buku Kedokteran EGC, Jakarta

Saparinto, C\& Hidayati, D,2006. Bahan Tambahan Pangan. Kanisius.Yogyakarta.Text Bookhttps://books.google.com/books?isbn=9792114408

Sulistyoningsih, 2011.Gizi untuk kesehatan ibu dan anak. Penerbit Graha IImu. Yogyakarta.

Restuastuti T,Jihadi M, Ernalia Y, 2016. Obesity; Food Pattern; Activity Pattern; Adolescent. Jom FK vol.3 No.I Februari 2016

Oktaviani W D* Saraswati L D* Rahfiludin M Z, 2012. Fast Food, Aktivitas Fisik, Pola Konsumsi, Karakteristik Remaja, Indeks Massa Tubuh (IMT). Jurnal Kesehatan Masyarakat Vol. 1, Nomor 2, Tahun 2012, Hal. 542-553

Pramono A, Sulchan M, 2012. Makanan Jajanan, Aktifitas Fisik Ringan, Obesitas Remaja. Jurnal Undip Vol. 2, Nomor 2, Juni 2014.

Yunita S, 2009. Kebiasaan Jajan Siswa Sekolah Dasar Kota Bogar Pdf. 